\title{
港湾区域における船舶交通管理の問題 一阪神港大阪区及び神戸区について一
}

\author{
斎藤 志穂 $^{*}$ 藤本 昌志 ${ }^{* *} \cdot$ 㴊 真輝 ${ }^{* *} \cdot$ 古莊 雅生 $^{* *}$
}

\section{The issue of vessel traffic Management in harbors - Osaka Area and Kobe Area in Hanshin port -}

\author{
Shiho SAITO, Shoji FUJIMOTO, Masaki FUCHI and Masao FURUSHO
}

\begin{abstract}
Two Administrative organizations manage the vessel traffic of the Osaka and Kobe areas in Hanshin port, the Harbor manager under the city government and the Harbor master under the Japan Coast Guard. The present vessel traffic management system isn't practical, and navigators may become confused due to the two different organizations. The purpose of this research is to investigate the present traffic management system from a navigator's view and to consider a new traffic management system needed by users.

We sent out questionnaires to pilots and interviewed the harbor manager, port radio officers, and harbor master. The results were subsequently discussed, and we suggest the following for the traffic management system in the Osaka and Kobe areas of Hanshin Port.

a) Harbor master controls violations regarding navigation in the port.

b) The administrations should provide plain and clear rules that bring common knowledge to navigators.

c) If a dangerous situation arises, port radio operators should support navigators with a unified traffic control system.
\end{abstract}

Keywords : Vessel Traffic Management, Harbor Management

\section{1. 研究背景 - 目的}

\section{1 亚神港大险区及び神戸区における船舶交 通管理体制}

港内の交通安全は、操船者個人の技術・判断なら びに行政の支援を含めた港内全体としての管理体制 によって図られている。現在、阪神港大阪区及び神 户区では、港内の交通管理に関わる組織として、管 理行政を担う港湾管理者と警祭行政を担う港長の二 者が存在する。

港湾管理者は「交通の発達及び国土の適正な利用 と均衡ある発展に資するため、環境の保全に配慮し つつ、港湾の秩序ある整備と適正な運営を図るとと もに、航路を開発し、及び保全すること(法第 1 条)」 を目的とする港湾法により定められる。港湾管理者
は港湾法上の港湾(港湾区域の定めのある港)の管理 を行うために置かれ、その業務は法第 12 条に定め られている。港湾管理者となり得るのは地方公共団 体のみであり、大阪港は大阪市が、神戸港は神戸市 が担っている。

一方、港長は「港内における船舶交通の安全及び 港内の整とんを図ること（法第 1 条）」を目的とす る港則法により定められ、法第 3 条第 2 項に規定さ れる特定港において海上保安官が任命され、海上保 安庁長官の指揮監督を受けて港則に関する法令に規 定する事務を掌る（海上保安庁法第 21 条第 1 項及 び第 2 項)。実際に港長業務を行っているのは、阪 神港大阪区では大阪海上保安監部、神戸区では神戸 海上保安部である。

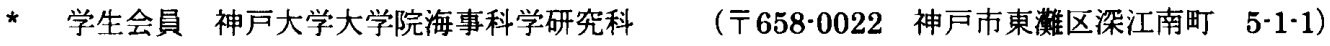

** 正会員神戸大学大学院海事科学研究科 (下658-0022 神戸市東灘区深江南町 5-1.1)
} 
このように、港湾管理者と港長の二つの行政組織 はそれぞれ異なる立場から港内の交通安全を図って おり、交通管理に関する具体的業務を個々に実施し ている。

行政二者それぞれの交通管理体制については、大 阪市港湾局が発行寸る『大阪港入出港マニュアル』 (1)及び神戸市みなと総局が発行する『入港マニュア ル』(2)（以下、総称して「入出港マニュアル」とす る）に記載されており、これらは各代理店を通して 本船に周知されていることになっている。

\section{2 港永管理者}

港湾管理者は、大阪港は大阪市（大阪市港湾局）、 神戸港は神戸市 (神戸市みなと総局) である。「大阪 港」「神戸港」という名称は港湾法上の港湾区域のこ とであり、港則法の港域である阪神港大阪区・神戸区 とは別に扱われるものである。しかし、両者は完全 に一致していないものの重なる部分が殆どであり、 本研究を進める上では「大阪区」「神戸区」として同 じ範囲として扱うこととした。

入出航マニュアルによると、港内交通管理に関す る港湾管理者の主な業務内容としては、以下の内容 が举げられる。

\section{(1) 運航調整}

各船が届け出た入出港に関する時刻を基に、船舶 が輻輳する水域や時間帯等の条件において、船舶同 士が危険な関係になるのを防ぐために通航時刻等を 調整するもの。

大阪区では平成 13 年 11 月より、新島造成工事に 起因する航路環境の変更に伴い、暫定主航路と南航 路の合流部および大関門付近において、総トン数 500 トンを越える船舶について運航調整が開始され た。

神戸区では、平成 18 年 4 月の港則法施行規則改正 による管制船トン数引き上げ（従来の総トン数 15,000 トン以上から総トン数 40,000 トン以上に変 更）に伴い、総トン数 500 トン以上の船舶のうち総 トン数 40,000 トン未満の船舶に対して、中央航路出 入り口付近での大型船同士の行会いや同時入航を防 止する目的で運航調整が開始された。

運航調整において通航時刻の調整を必要とする船 船に対しては、港湾管理者が代理店を通じて変更を 要請する。港長側が行う航行管制は強制力を持つの に対し、港湾管理者側の運航調整はあくまで行政指 導である。

（2）ポートラジオによる情報提供

ポートラジオとは、電波法施行規則及び電波法関
係審査基準により定められた海岸局の名称で、『港湾 管理事務及び入出港船舶の航行の能率化を図るため 港湾通信業務を行う』ことを目的として船舶の航行 安全に寄与し港湾管理運営を支援する機関である。 ポートラジオは港湾管理者に委託された民間企業が 運営しており、大阪区には「大阪ポートラジオ」が、 神戸区には「神戸ポートラジオ」が存在する。ポー トラジオは各船及び各港湾関係業者等との連絡空口 であり、船舶の動静把握を随時行い、他船の動静情 報など船舶の入出港をサポートするための情報提供 を行っている。入出港に当たってのポートラジオへ の通報時期及び内容は、入出港マニュアルに規程、 周知されていることとなっている。

\section{（3）その他}

入出港マニュアルを見ると、大阪区・神戸区それ ぞれの港湾管理者が他にも独自の安全対策を実施し ていることがわかる。

大阪区では、「大阪港航行安全情報センター」によ り、港内海上工事等に関する情報提供と共に電光掲 示板による入出港状況の表示が行われている。

神戸区では、水先人要請に関する行政指導を設け たり、中央航路入り口（南側）付近の整流を目的と した『周辺海域安全情報図』を示している。

\section{3 港 長}

一方、港長業務は、大阪区は大阪海上保安監部、 神戸区は神戸海上保安部が担当している。両港域の 入出港マニュアル及び『瀬戸内海水路誌』には、港 長側の港内交通管理として、主に次のことが記載さ れている。

（1）港則法の規定（一部抜粋）及びそれに準じて定

\section{められたルール}

港則法の規定の中から、(1)錨地の指定、(2)移動の 制限、(3)航路及び航法、(4)進路の表示の部分が抜粋 され、記載されている。また大阪区の入出航マニュ アルには、新島建設工事に伴って港長が公示した「錨 泊禁止及び航行等の制限」が記載されている。

\section{(2) 航行管制}

港則法第 36 条の 3 (船舶交通の制限等) により、 特定港内の国土交通省令で定める水路において、信 号によって一定トン数以上の船舶が行き会わないよ うに管制を行う業務。

大阪区では、木津川運河水面（管制船舶 300 総卜 ン以上、管制対象船舶 300 総トン以上）及び南港水 路（管制船舶 5,000 総トン以上、管制対象船舶 500 総トン以上）での管制が行われている。

神戸区では、中央航路（管制船舶 40,000 総トン以 
上、管制対象船舶 500 総トン以上）での管制が行わ れている。

（3）管制情報の提供

管制情報については、VHF や船舶電話にて、直接 大阪海上保安監部又は神戸海上保安部に確認するこ とが出来る。

\section{4 「货物船レッドナクレ（レ号）你物船ス カイデューク (ス号) 年突事件」に見る現 行体制の問覧点}

平成 18 年 9 月 8 日に神戸港において発生した「貨 物船レッドナクレ (レ号) 貨物船スカイ デューク

（ス号）衝突事件」の海難審判裁決録(3)では、現行 の船舶交通管理体制における問題点の一例を見るこ とが出来る。

この事件は、神戸中央航路を航行し入港するレ号 と、六甲アイランド RC5 岸壁を出港するス号とが神 戸中央航路内の防波堤入口付近で衝突のおそれがあ る態勢で接近し、衝突に至ったものである。

本件における適用航法としては、航路航行船優先 を定めた港則法第 14 条第 1 項と、防波堤の入り口 付近における出船優先を定めた同法第 15 条とが考 えられる。しかし、防波堤の入り口付近の航路は航 路全体の一部分であり、航路全体についての航法を 一般的に規定している法第 14 条に対し、第 15 条は その部分を含む水域を特別な水域として指定し特別 な航法を定めたものであるため、特別法優先の原則 に従って第 15 条が優先して適用されることが長年 にわたり確立されている。

しかし本件では、港則法第 14 条第 1 項が適用さ れた。航法の適用にあたり、事件当時の状況や両船 の大きさ・操縦性能などとともに、神户港港湾管理 者作成の『入港マニュアル』(4)に記載された運航調 整実施要領が考慮された。当時の入港マニュアルで は、管制信号が F の点滅時（この場合、総トン数 40,000 トン未満の船舶は航路に自由に入出航する ことが出来る)には港則法第 14 条の航法を遵守する よう記載されている(現在の入港マニュアル(2)では、 港則法第 3 章「航路及び航法」に規定された航法全 体を遵守するよう記載されている)。

先行研究 ${ }^{(5)}$ では、このように法律以外の行政指導 が存在し、それが法律の解釈と一致していないとい うことは、日本船舶のみならず、外国船舶にとって も混乱や誤解を招く要因となっていることを指摘し ている。

\section{5 目的}

本研究では、阪神港大阪区及び神戸区における港 内の船舶交通管理が役割や権限の異なる二つの行政 によって其々で行われていることに関連し、前述し た海難審判裁決録の例のように、操船者にとって不 都合な問題が存在しているのではないかと仮定した。 本研究ではまず、操船者から見た現行の交通管理体 制上の問題点を明らかにし、その内容を分析し、問 題の原因を探り、それを基に阪神港大阪区及び神戸 区で求められる港内交通管理体制について検討する ことを目的とした。

\section{2. 调查方法}

本研究では、阪神港大阪区及び神戸区における現 行の交通管理体制の問題と原因を探るため、港湾管 理者と港長の行政二者、そして現場を航行する操船 者(水先人)の三つの立場を対象として調査を行った。 具体的には、【調查 A】水先人に対するアンケート調 査、【調査 B】港湾管理者と港長への聞き取り調査を 行った。

\section{1 水先人に対するアンケート㽢查【胡古 A】}

本研究では、阪神港大阪区及び神戸区を航行する 操船者の中でも、特に航行頻度が高く水域情報にも 詳しい「水先人」に対象を絞り、操船者の立場から の意見を抽出するべくアンケート調査を実施した。 調查は平成 21 年 8 月から9 月にかけて、大阪湾水先 区水先人 (総員 106 名) のうち平成 21 年 3 月時点で 港内業務に従事する水先人 59 名を対象とした。

アンケートの質問項目は以下の通りで、回答は記 述形式とした。

(1) 港内業務経験年数

(2) 港内業務中、他船（港内を航行するあらゆる種類 の船舶を対象とする）の行為が原因で、自船の操 船上困難な状況が生じた事例について、その内容 と相手船の種類。(これにより、港内に実在する船 舶交通上の問題点を把握する)

（3）港内業務中、港湾管理者（ポートラジオを含む） 及び港長が行う交通管理業務に関連した事項（以 下に示す $\mathrm{i}$ 〜 viのずれかが原因で、操船上困難 な状況が生じた事例）について、その原因及び状 況。(これにより、行政による交通管理業務に関連 した問題点を把握する)

i . 法律や行政指導等の規則に規定された内容に 関すること

ii . 海上保安監部（又は海上保安部）からの情報 提供に関すること

iii. 航行管制・信号に関すること 
iv. ポートラジオからの情報提供に関すること

$\mathrm{v}$. 運航調整に関すること

vi. その他の港湾関保者に関すること

(4) 阪神港大阪区及び神戸区における船舶の交通管 理体制に関する要望事項。

なお、(2)と(3)については大阪区及び神戸区のそれ ぞれについて質問した。

(2)及び(3)で得られた回答は、6 人で $\mathrm{KJ}$ 法（川喜田 二郎氏によって考案され、細分化されている情報を 統合し、まとめてゆく手法，1967）に従って分類を 行い、操船者から見た現行の交通管理体制上の問題 点を明らかにした。

\section{2 港洼管理者及び港長への聴き取り調查 【調查 B】}

大阪・神戸それぞれの港湾管理者（ポートラジオ を含む）と港長に対して、以下の通り実務現場の見 学と聴き取り調查を実施した。

\section{（1）港湾管理者}

大阪区に関しては、平成 21 年 12 月に大阪市港湾 局の運航調整業務担当職員 1 名、及び大阪ポートラ ジオ職員 1 名に対し調查を行った。また神戸区に関 しては、平成 21 年 12 月に神戸市みなと総局の運航 調整業務担当職員 1 名に、平成 21 年 5 月に神戸ポ ートラジオ職員 1 名に対し調查を行った。

質問内容は以下の通りである。

<港湾管理者 $>$

・ 運航調整業務の方法・流れについて

・ ポートラジオとの連携について

・海上保安(監)部との連携について

- その他

くポートラジオ>

- ポートラジオの具体的な業務内容について

・海上保安(監)部との連携について

- その他

\section{（2）港 長}

平成 21 年 7 月に、大阪海上保安監部及び神戸海 上保安部にて港長業務に携わる職員それぞれ 1 名に 対し調査を行った。

質問内容は以下の通りである。

・ 航行管制業務の流れ、方法について

- 港湾管理者側との連絡調整について

・港則法等の規定違反への対応について

- その他

\section{3. 結 果}

3.1 水先人に対するアンケート倜笨【調查 A】 結果

水先人に対するアンケート調查では、対象者 59 名中 23 名から回答を得た (回答率 $39 \%$ )。各質問項 目に対する結果は以下の通りである。

\subsection{1 港内策務経硂年数}

回答者の港内業務経験年数を 5 年ごとに 4 つの段 階に分類すると、 5 年末満 13 名 $(57 \%) 、 5$ 年以上 10 年末満 2 名 $(9 \%) 、 10$ 年以上 15 年末満 4 名 $(17 \%)$ 、 15 年以上 4 名 $(17 \%)$ であった。

\subsection{2 他船の行為に関する問題点}

2.12(2)で述べた質問項目に対する回答を分類した 結果、大阪区・神戸区それぞれにおいて(1)〜(3)に示 す問題点が得られた（各項目の見出しは分類によっ て導かれた問題点であり、文中ではその具体的な要 素について述べる)。

大阪区では、以下の 3 つの問題点が主に挙げられ た。([ ]内は該当する船舶)

（1）港則法及び海上衙突予防法の規定不覃守

[漁万う船、No Pilot 外航船、総トン数 500 トン 以上の内航船、港則法上の小型船及び雑種船]

漁万う船については、第 5 区暫定主航路周辺で 他船の航行の妨げとなるような操業が行われてい る点が挙げられた。No Pilot 外航船、総卜ン数 500 トン以上の内航船、港則法上の小型船及び雑種船 については、港則法第 14 条(航路における航法)、 第 15 条 (防波堤入り口付近の航法)、第 18 条（雑 種船・小型船の航法)、及び海上衝突予防法 (以下 「予防法」とする）第 9 条（狭い水道等における 航法)を遵守しない事例が多く挙げられた。また、 新島建設工事に伴って定められた「航行等の制限」 に従わない航行事例も挙げられた。

（2）強引な横切り・追い越し・割り込み、急な減速 など、他船を危険な状況に追い込む行為

[No Pilot 外航船、総トン数 500 トン以上の内航船]

これらは、法律の規定には当てはめることがで きない事例であり、他船の危険を考慮しない船員 としてのマナーに久ける行為が問題として、最も 多く挙げられた。第 3 区の港大橋付近や、大関門 及び南港関門付近、また暫定主航路と南航路の合 流部が主な発生海域である。

（3）複数船舶の同時間带入出港において、タグを使 用しない船舶や錨を使用する船舶が他船の航行を 
妨害

[No Pilot 外航船、総卜ン数 500 トン以上の内航船］

このような事例は第 3 区の港大橋付近で最も多 く見られ、第 4 区の R 岸壁・L 岸壁付近でも見ら れる。タグを使用しない船舶や錨を使用する船舶 が長時間周辺水域を占領してしまうため、同時間 帯に入出港する船舶が不安全な状態で待機せざる を得なくなる場合や、危険な航行を余儀なくされ る場合がある。

神戸区では、以下の 3 つの問題点が主に挙げられ た。（[ ]内㤥当する船舶）

\section{（1）港則法及び海上衝突予防法の規定不趡守}

[漁ろう船、No Pilot 外航船、総卜ン数 500 トン 以上の内航船、港則法上の小型船及び雑種船］

神戸区では、特に中央航路内やその付近での漁 ろう船の操業が多く挙げられた。また第 2 区では、 ポートアイランド第 2 期埋立地東側の倸留施設に 出入りする No Pilot 外航船や総トン数 500 トン以 上の内航船が、港則法第 12 条（航路航行義務）に 反してショートカットする事例が挙げられた。第 3 区では港則法第 18 条（雑種船・小型船の航法） に従わない艀や小型内航船の存在が挙げられた。

（2）強引な横切り・追い越し・割り込み、急な減速 など、他船を危険な状況に追い込む行為

[No Pilot 外航船、総トン数 500 トン以上の内航 船、港則法上の小型船]

最も指摘されたのは、中央航路内及び航路出入 り口付近での強引な行為である。管制船が航路を 航行中に非管制対象船である小型船が航行を妨げ る例や、航路入航の際の他船の強引な割り込み、 航路内での他船の急な減速等が挙げられた。また、 第 3 区六甲アイランド南側係留施設と第 7 防波堤 間の狭い水道においても、大型船の入出港中に他 船が強引に航行する行為が見られる。

（3）被数船舶の同時間带入出港において、タグを使 用しない船舶が他船の航行を妨害

[No Pilot 外航船、総卜ン数 500 トン以上の内航船] これは第 2 区のポートアイランド第 2 期埋立地 東側係留施設周辺で見られる。タグを使用しない 船舶が狭い水域で離着栈に長時間要し、他船の入 出港の妨げとなっている。

\subsection{3 行政による交通管理莱務に関遇した問題 点}

2.1(3)で述べた質問項目に対する回答を分類した 結果、大阪区・神戸区それぞれにおいて(1)〜(5)に示
す問題点が得られた（各項目の見出しは分類によっ て導かれた問題点であり、文中ではその具体的な要 素について述べる)。

大阪区では、以下の問題点が挙げられた。

\section{（1）交通法規不逼守への対応不足} 航法規定や港内での漁ろうの制限、港長公示に よる航行制限に違反する船舶が存在する一方で、 その対策が不十分であることが挙げられた。

（2）ルールの適用が不明確

特に暫定主航路と南航路との合流部における航 法の適用について、操船者にとっては不明確であ るとの問題が挙げられた。予防法第 15 条 (横切り 船の航法）を適用して操船判断をしていると思わ れる No Pilot 外航船の存在も指摘された。

（3）運航調整等の行政指算の限界

港湾管理者が運航調整を行っていても入出港予 定表の時刻変動は常にあること、ポートラジオへ の通報を行わない船舶の存在等により、予期せぬ 危険な状況に遭遇することが挙げられた。

（4）航行管制に伴って生じる危険

航行管制に伴い、長時間のドリフティングを余 儀なくされたり、航路内で待機中の船舶の接近な どが挙げられた。

（5）ポートラジオの立場を誤解する No Pilot 外航船

特に No Pilot の外航船では、ポートラジオを管 制機関と誤解しているような場合があり、そのよ うな船舶が危険な状況をもたらしたケースが挙げ られた。

また神戸区では、以下の問題点が挙げられた。

（1）交通法規不䢙守への対応不足

航法規定や港内での漁ろうの制限に違反する船 舶が存在する一方で、その対策が不十分であるこ とが挙げられた。

\section{（2）ルールの適用が不明確}

神戸中央航路北側入り口での航法適用が不明確 である点が挙げられた。特別法優先の原則に従い、 港則法第 14 条第 1 項に優先して同法第 15 条が適 用される部分ではあるが、前述の「貨物船レッド ナクレ (レ号) 貨物船スカイ デューク (ス号) 衝 突事件」での裁決例もあり、操船者に迷いをもた らしている。また操船者が特別法優先の原則を理 解していない場合もあり、航法を明確に示して欲 しいとの意見も聞かれた。

（3）運航調整等の行政指導の限界

港湾管理者が運航調整を行っていても入出港予 
定表の時刻変動は常にあり、予期せぬ危険な状況 に遭遇することが挙げられた。

\section{（4）航行管制に伴って生じる危険}

大阪区同様、待機中の船舶の危険が挙げられる と共に、管制信号の切り替えと同時に動き出す船 舶がもたらす危険等が指摘された。現場の状況を 考慮せず単純に信号が変わるのみであることに対 し、問題視する意見が聞かれた。

（5）情報提供のみ可能なポートラジオ

港内の詳しい船舶動静監視を行っているポート ラジオだが、情報の入手・提供のみが可能であり、 船舶に指示を出す権限までは持っておらず、危険 な状況下で効率的に生かせていないという意見が 聞かれた。

\subsection{4 港内の交通管理体制に関する要望事项}

水先人の立場から、港内の交通管理体制に関して 望むこととして、主に以下の知見が得られた。

・まずは航行船舶が規則を遵守するような対策（取 り締まり等）を強化すべきである。

・操船者が判断に迷うことの無いような、その水域 におけるより安全で明確な規則を定めて欲しい。

・責任を持って航行管制を実行できる機関が必要で ある。単に情報を提供するのみではなく、不安全 な運航をしている船舶に対して規制を行う権限を 有する機構が期待される。

・港内操船ノウハウを十分に理解したポートラジオ 担当者の配置及び情報提供が求められる。

・ポートラジオが唯一の状況監視機能であれば、管 制機能が付加されるべき。

\section{2 港流管理者及び港長への聴き取り調査 【倜查 B】結果}

大阪及び神戸の両港湾管理者（ポートラジオ含 む)・港長の実務現場見学と聞き取り調查により、得 た内容は以下の通り。

\subsection{1 港流管理者}

大阪・神戸ともに、海上保安(監)部の航行管制担 当官からの情報を元に細かな調整を実施していた。 代理店とは電話等で密に連絡をとり合い、運航調整 の時刻を決定している。また夜間もポートラジオを 通して時間変更を受け付けている。現在は、電話に よる港湾管理者・代理店・ポートラジオ間等での 3 者通話が可能であり、スムーズに情報交換が出来る 態勢となっている。

大阪区では、運航調整担当官が大阪ポートラジオ
に出向いて業務を行っており、連絡調整が行い易い 環境となっている。

神戸区では、早朝の運航調整において「出航管制 船がなく、入航船が 7 隻以上の場合」との条件を設 けているが、その条件に相当しない場合であっても、 港湾管理者が危険であると判断した場合は時間調整 を要請している。

\subsection{2 ポートラジオ}

大阪・神戸のどちらのポートラジオも、主要な航 路が見渡せる立地環境にある。双眼鏡やライブカメ ラによる目視での見張りを行うと同時に、レーダー やAIS を用いて常時船舶の動静を把握し、各船の最 新の情報を収集・管理している。

ポートラジオは港湾関係各所や水先人会事務所、 航行管制担当者との連絡空口となっており、本船と 各所との連絡調整を行う中枢となっている。入出港 マニュアルの中でポートラジオへの通報時期と内容 を明記しているが、No Pilot の外航船や不定期で入 航する船舶の中には、指示通りの通報を行わない船 舶も多いのが現状である。

ポートラジオから本船に対しての通信では、情報 提供やアドバイスのみ可能であるため、オペレータ 一の言葉が指示する形とならないよう気を配ってい る。しかし、No Pilot 外航船がポートラジオのオペ レーターを管制官と勘違いしている場合もあり、外 国人操船者にとっては理解しにくい存在であること が窥える。

\subsection{3 港 長}

大阪・神戸とも、航行管制は信号所内ではなく海 上保安(監)部内にあり、他部署との連携が保ちやす い環境となっているが、管制現場を直接見張りする ことは出来ない立地条件である。船舶の動静監視は、 主に AIS 搭載船舶の動静を把握するモニタとレーダ 一、ライブカメラによって管制水路周辺を中心に行 われている。船舶の動静監視中に本船に注意を促し たい事項が生じた場合は、ポートラジオのオペレー ターを通じて内容を伝えている。

航行管制はマニュアルに沿って時間設定をしてい くが、待機中の船舶が存在する場合などは、管制船 が航路を出た後で危険が無いようならば、計画より も早い時間に信号を切り替えることがある。その場 合は、ポートラジオと密に連携をとっている。

管制官は海上保安(監)部の一職員であるが、直接 違法行為を取り締まる権限は無い(実際に権限を有 するのは他部署である)。港則法の違法行為に関する 
通報は年間に 2 3 件程度であり、ほとんどが水先人 からの通報である。現在のところ、海上保安(監)部 が積極的に現場に出て取り締まることはしていない。

\section{4. 考 察}

以上 2 つの調查で得た結果から、その関連性を考 察し、船舶交通管理上の問題点及び原因を明らかに する。さらに、阪神港大阪区及び神戸区において求 められる港内交通管理体制について検討する。

\section{1 船舶交通上の問百点と交通管理体制}

水先人に対するアンケート調查結果を大阪区・神 戸区で比較すると、船舶交通上の問題点、各行政の 交通管理業務に関連した問題点共に、細かな違いは あるものの同種の問題点が举げられていることから、 大阪区・神戸区の各行政機関は、それぞれの港域に 合った独自の対策も展開しながら交通管理を行って いるものの、問題の根本は両者に共通した基本的な 体制の中にあると考えられる。

\subsection{1 交通法規の道守に関する問題}

調查 A からは、交通法規を遵守しない船舶が多い こと、港長側による対応が十分でないという意見が 得られている。また調查 $\mathrm{B}$ の港長に対する聴き取り からは、航行管制を行う管制官には実際に違反行為 を取り楴まる権利がないこと、現在のところ海上保 安(監)部による積極的な現場での取り締まりはして いないこと、違反行為に対する通報は主に水先人か ら年に 2 3 件寄せられる程度であることが示され た。

これらの結果から、港内で交通法規の不遵守が発 生している一方で、効果的な対策が取られず放置さ れた状態にある、という問題点が明らかとなった。 責任を持って違法行為を取り締まる存在が必要であ ると考える。

\subsection{2 法律や行政指学の内容に関する問題}

調查 A では、法律の規定に触れない範用での危険 行為が多い現状や、運航調整等の行政指導の限界、 大阪区ではポートラジオの立場を誤解する No Pilot 外航船が危険をもたらすケース、が問題として得ら れた。また調査 B のポートラジオへの聴き取りから も、入出港マニュアルで指導しているにも関わらず ポートラジオに通報しない船舶が存在する点が挙げ られた。これらのことから、港内交通現場では操船 者の臨機の対応で危険を回避せざるを得ない状況が 在り得るということがわかった。
その一方で調查 Aでは、ルールの適用が不明確で あること、ローカルルールに対する操船者の理解不 足や誤った解釈が生じている現状が指摘された。

よって、港内交通現場では操船者の臨機の対応が 求められているにもかかわらず、ルールの不明確さ が操船者の判断や共通認識を妨げ、操船者に困難な 状況をもたらしていると考えられる。

\subsection{3 交通管理機関に関する問题}

ポートラジオと航行管制官に関して、立場、交通 監視環境、通信・連絡等という観点で比較しまとめ ると、次のようになる。

くポートラジオ >

・立場

港湾管理者に業務委託を受けた民間会社

\section{- 交通監視環境}

港内を直接見渡すことのできる立地条件にあり、 肉眼やライブカメラ、レーダー、AISによって港 内全体を監視できるようになっている。

\section{·通信・連絡等}

船舶や港湾関係各所、航行管制官との連絡調整 の主体を担い、常時船舶動静情報の収集や提供を 行っている。

\section{＜航行管制官＞}

・立埸

\section{警察行政を担う公の立場}

\section{・交通監視環境}

港内のほとんどは見渡すことができない立地条 件であり、主にライブカメラやAIS、レーダーに よって管制水路を中心に監視が行われている。

\section{・通信・連絡等}

関係各所からの情報をもとに管制信号を調整し ている。また、ポートラジオを介して本船にアド バイスを行うこともある。

この比較からは、港内において警察行政の立場に ある航行管制官に比べて、民間のポートラジオの方 がより詳しい交通監視・情報収集を行うことが出来、 船舶や関係各所との通信・連絡主体として体制が整 っていることがわかった。

またこれらの交通管理機関に関して、調查 Aでは 航行管制に伴って新たな危険が生じること、また責 任を持って管制を実行できる機関がほしい、不安全 航行に対する規制をしてほしいという要望が挙げら れた。 
また同じく調査 A から、ポートラジオの立場を誤 解する No Pilot 外航船が危険をもたらすこと、ポー トラジオは航行管制官に比べて詳しい交通監視を行 っているにもかかわらず船舶に指示を出す権限は持 っていないこと、が指摘された。調査 Bからも、ポ ートラジオを管制機関だと誤認している No Pilot 外航船の存在が明らかとなった。

以上のことから、現在の航行管制官が行う管制で は港内全体の交通流が考慮されにくい状況であるの に対し、港内の詳しい交通監視が可能なポートラジ オは立場上情報提供しかできない、という非効率性 の問題が考えられる。また No Pilot 外航船にとって ポートラジオの立場が曖昧でそれに伴う危険が生じ ることも、異なる二つの機関が関わっていることに よる弊害であると考える。

\section{2 服神港大阪区及び神戸区で求められる港 内交通管理体制}

以上の問題点を踏まえ、阪神港大阪区及び神戸区 で求められる港内交通管理体制について検討する。

(1) 港長による現場監視・運法行為取り締まりの強化

交通法規の不順守が放置されている問題に対して は、違法行為の取り締まりの強化が求められる。ま ずは基本的な航法規定等が遵守されるような環境を 作ることが必要であり、そのためには警察権を有す る港長側の積極的介入が不可欠であろう。港則法に は罰則規定が設けられているにもかかわらず、取り 締まりがほとんど行われていないため、現在はそれ らの規定が十分に生かされていない状態にあると考 えられる。よって、違法行為や事故を未然に防ぐた めにも現場監視を強化し、違反行為に対して峳然た る態度を示し、操船者の安全意識を向上させること が必要であると考える。

(2) 外国人操船者にも理解しやすい明確なルールの 設定

ルールの不明確さが操船者の共通認識を妨げてい るという問題に関しては、外国人操船者にも理解し やすい明確なルールの設定が求められる。強制水先 の対象が 1 万トン以上の船舶となって以来、No Pilotで港内を航行する外航船は増えている。行政指 導などローカルルールの設定は、外国人操船者や阪 神港航行程験の少ない操船者に誤解をもたらさない よう、できる限りシンプルで国際ルールに則した内 容であるべきと考える。

(3) 船舶に対する交通管理の一元化

港内全体の交通流が考慮されにくい航行管制とな
っている問題、ポートラジオの立場が曖昧であると いう問題に関しては、港内交通管理の要として動静 監視や連絡調整、管制業務などを一元的に行う機関 の存在が求められる。具体的には、船舶との港務通 信の主体を担うポートラジオに管制業務を委託し、 操船者に対する管理空口を一つにし、一元的な交通 管理体制を構築してはどうかと考える。ポートラジ オは、より充実した交通監視が可能な設備や立地条 件が揃い、船船の動静情報を常時把握し、船舶や関 倸各所との通信・連絡主体を担っているため、現場 の交通流を考慮した管制を行うには適している。ま た現場の状況によっては、船舶に入出港の順番を指 示出来るような権限を持つことも必要であると考え る。ただし、ポートラジオが民間であることから、 本来“官”が担うような権限を委託することがどこ まで可能なのかという法的な問題については、また 別に検討しなければならない。

\section{5. 結論}

本研究では、阪神港大阪区及び神戸区における船 舶交通管理体制の問題点を明らかにするため、水先 人を対象としたアンケート調査を行い $\mathrm{KJ}$ 法により 分類した。また、港湾管理者及び港長の船舶交通管 理業務の実際について聴き取り調査を行った。これ らの結果より、次の結論を得た。

（1）港内の船舶交通管理が役割や権限の異なる二つ の行政組織（港湾管理者・港長）により其々に 行われていることに関連し、次のような問題点 が存在する。

(1) 交通法規不遵守の放㯰

(2) ルールの不明確さが操船者の判断や共通認識を 妨げている

(3) 航行管制において港内全体の交通流が考慮され 難い一方、現場監視が容易なポートラジオは立 場上情報提供しかできない、という非効率性

（2）これらの問題を解決する為には、港長による現 場監視・違法行為取り締りの強化、明確なルー ルの設定、船舶に対する交通管理の一元化が必 要である。

\section{期辞}

本研究にご協力いただいた大阪湾水先区水先人の 皆様、大阪市港湾局の西村様、神戸市みなと総局み なと振興部海務課港務係の皆様、大阪ポートラジオ の皆様、神戸ポートラジオの皆様、大阪海上保安監 部航行安全課及び港内交通管制室の皆様、神戸海上 
保安部航行安全課の皆様に、厚く御礼申し上げます。

\section{考考文献}

（1）大阪市港湾局・大阪港航行安全情報センター： 大阪港入出港マニュアル, 平成 21 年 10 月

（2）神戸港港湾管理者：入港マニュアル，2008 年 4 月

（3）平成 19 年 3 月 28 日神戸地方海難審判庁裁決 http://www.mlit.go.jp/jmat/saiketsu/saiketsu_ kako/19nen/koube/kb1903/18kb118yaku.htm

（4）神戸港港湾管理者：入港マニュアル，2006 年 4 月

（5）藤本昌志：海上交通行政における規制緩和に関 する問題, 阪大法学, 第 58 巻, 第 $3 \cdot 4$ 号, pp249-270, 2008.11

\section{罢疑度答}

五十首一馬（住友金属物流株式会社）:

（1）操船者を水先人のみに限っていますが、これ は利用者の一部に限られ、一般性に欠けるのでは ないでしょうか。 （2）ポートラジオの権限強化とのご意見ですが、 名古屋のような港内マーチスの設置が効果的では ないでしょうか。

\section{齐藤志穂 :}

（1）本研究では、時間の都合のため操船者を水先 人のみに絞ることとしました。確かに操船者全体 としての意見を明確にする為には、港内を航行す る様々な船舶の操船者に対して調查を行う必要が あり、その結果によっては違った問題点が明らか になる可能性もあると考えます。その点は今後の 課題にしたいと思います。

（2）現在のポートラジオは、現場監視に好都合な 条件が揃い、船舶の動静情報をタイムリーに入手 することも可能であり、現場の交通状況を把握し た上で船舶や港湾関倸各所との連絡調整を行うこ とが出来る体制が整っています。新たに海上交通 センターを設置せずとも、ポートラジオに管制権 を委託することにより、現在整っている体制を生 かしてより現場の状況に適した交通管理が出来る のではないかと考えます。港湾関係各所との連絡 調整の面からも、ポートラジオによる一元管理が 好都合であると思います。 